\title{
Effects of climate change and its impact on some variables that influence the quality of life of populations in Latin America.
}

\author{
Ana Milena Garcia ${ }^{1}$, Elizabeth Malagón-Sáenz ${ }^{2}$, Nancy Patricia García-Pacheco ${ }^{3}$, \\ Javier Mauricio Garcia-Mogollón ${ }^{4}$ \\ ${ }^{1,4}$ Universidad de Pamplona, Pamplona - Colombia, ${ }^{2,3}$ Universidad Santo Tomás, Cúcuta - Colombia, \\ ORCID: ${ }^{1}$ 0000-0002-3563-0382, ${ }^{2}$ 0000-0002-4322-3832, ${ }^{3}$ 0000-0001-5161-5214, ${ }^{4}$ 0000-0001-7423-8909
}

Recibido: 05 de agosto de 2020.

Aprobado: 11 de noviembre de 2020.

\begin{abstract}
This article provides a bibliographic review of the effects of climate change on various currently prevailing topics deemed critical. Humanity faces enormous challenges in the areas of agricultural production, food security, sustainable development, the environment, and their relationships and impact on poverty.

It is essential to adapt the 2030 Agenda for Sustainable Development in Latin American and Caribbean countries in order to fulfill proactive actions for attaining the Sustainable Development Goals (SDGs). Each Country must develop its own solutions according to the best interests of their citizens and country.

A review of topics including climate change and its affiliation with social progress indexes, unemployment, intensity of deprivation, and indicators of sustainable development are key to inspiring companies to adopt good corporate social responsibility practices. A longitudinal design was applied to the non-experimental research in order to examine changes throughout time over populations of people living in LAC countries. An analysis of the changes that occurred to populations over time was divided into three sections.

Keywords: Climatic change, food security, global reporting initiative (GRI), poverty, sustainable development goals, (SDG), quality of lifeBibliometric analysis; Social network analysis; Co-word analysis; Smart City.
\end{abstract}




\section{INTRODUCTION}

The perception of different authors and organizations demonstrates an increasing interest in the effects and variations that climate change produces on our planet. Each day the interaction between man and its ecosystem becomes more concerning. This addition to the inequalities of human development poses a critical obstacle to making the 2030 Agenda a reality for sustainable development [1].

There is a growing connection of problems which creates a nexus between water stress, energy, and food security. This nexus is based in scenarios that try to anticipate key points of inflection that can rapidly affect these factors. Extensive planning is necessary in order to anticipate the associated risks to the population through integration, development, cost and benefit evaluation, and effects of mitigation or adaptation.

According to [2, p. 8] in many regions of the world, there is a medium level of confidence that the duration or number of hot spells or heat waves has increased.

There is an abundance of evidence that shows that climate change results in longer, more frequent, more intense, and farther-reaching heat waves. Results show that the risk of Europeans living with high heat stress increases constantly. From $0.4 \%$ to $20.3 \%$ and $32.6 \%$ to $48.4 \%$ in $2050[3]$.

This demonstrates how the problems caused by climate change are irreversible since the particles in the atmosphere last for many years. The consequences of this change have been well documented both by experts and by the impact it has on many people worldwide.

Additionally, a profound alteration in the composition of the atmosphere due to the natural variability of the climate poses a threat to humans. Every day the planet continues to show urgency in the need to focus efforts in reducing poverty and the vulnerability of humanity in the face of climate change. These changes not only impact humans, but animals as well. A decrease in pollinators as a result of climate change could have significant impacts on agricultural production [4].

The threat of adverse effects insinuates numerous unfavorable impacts not only in agricultural production, but in other industries as well. Adaptation strategies are vital in dealing with the adverse effects of climate change. The inability of farmers to adapt to climate change can lead to difficulties such as forced relocation, social interruption, sickness, and death [5].

In order to maintain an average global temperature rise under $2^{\circ} \mathrm{C}$, it is necessary to reduce greenhouse gas emissions (GHG) by at least $80 \%$. The rate at which greenhouse gases are emitted into the atmosphere causes the heat that would normally be irradiated into space to become trapped in the atmosphere of the earth causing the temperature to increase. Carbon dioxide is absorbed by the oceans which are then emitted into the atmosphere through a naturally occurring process [6].

Closing the gap between the predictions in climate models on a large scale and climate reality on a small scale is a key theme in researching water management. Although, advancement in more developed countries has continued, tropical regions still lack the necessary information about possible discrepancies between climate models and measurements. This causes water resource managers to rely on their experience rather than scientific data in their future planning. This is an even bigger problem in tropical and mountainous regions where there is an ever-increasing demand for water and where the effects of climate change will be bigger [7].

The effects of global warming on crops, food production, coastal areas, and human development will cause suffering due to water stress and lack of energy in the world.

This study reviews several topics relating to development around climate change and greenhouse gas emissions in Latin American countries compared to countries belonging to the Organization for Economic Cooperation and Development (OECD), public policies, poverty, and food security.

\section{SUSTAINABLE DEVELOPMENT}

According to Ruiz (2013) there is a specific problem when it comes to educating society and organizations about the environment. There is a general lack of social responsibility within business management due to a lack of environmental culture or lack of training.

This leads to a culture which avoids the implementation of ecological policies, programs, and activities. Some of the measures essential to be adopted are: reduction of the degradation of the land, the loss of biodiversity and air pollution, the land and waters, improve water and resource management, mitigate and adapt to climate change, use resources with efficiency, address decarbonization, decoupling and detoxification, and prevent and manage risks and disasters [8, p. 7].

The majority of companies have not been able to create an environmental education plan due to a lack of clear environmental consensus.

Furthermore, the impact of climate change on society will bring abrupt changes which will need to be studied by governments and people all around the world. This will not affect everyone equally, but rather have a disproportionate effect on those who have not been able to act and adapt to different business opportunities.

As a result, replacing economies centered on fossil fuels and reducing worldwide poverty will become incredibly important.

Adaptation does not have a well-defined measurement of effectiveness unlike mitigation. Each problem caused by climate change is unique and must be solved in a specific way [9, p. 14].

The dynamics of productivity on earth reflect the quality of soils and their use. Its management is based on environmental conditions and its constant deterioration indicates that over a long period of time the health and productivity of the soil decreases. This creates both a direct and indirect repercussion in virtually every ecosystem and the services that they provide. 
The gravity of the risks and potential impacts is particularly high especially for less developed countries and vulnerable communities due to their limited capacity to combat these issues. According to the IPCC it's probable that an increase in the average global temperature will change precipitation and atmospheric humidity. It is almost a certainty that anthropogenic activity is the principal cause of global warming.

The GRI (Global Reporting Initiative) is an independent international organization that has been the pioneer in corporate sustainability reports since 1997. They have various entities that recognize and convey their impact in terms of sustainability. These criteria include climate change, human rights, and corruption.

In a 2015 study implemented by GRI (Global Reporting Initiative), Latin America signaled that the directors surveyed had a conceptual vision of sustainability and had realized its relevance. Every 4 out of 5 participating directors associated the concept of sustainability with corporate strategy or that it was an integral part of the economic, social, and environmental vision of the company.

More than 50.9 million hectares of agricultural produce was considered organic in 2015 (Includes the areas in process of certification) representing $1.1 \%$ of all agricultural land in the world [10].

Organic products have some of the best standards of sustainability in terms of variety and area. As its recognition of sustainability increases and companies can decide how to report their various activities. These reports can allow for the identification of opportunities with these new challenges allowing for the planning of strategies through specific indicators to demonstrate strengths and weaknesses and create a more efficient operation.

The objectives of sustainable development (ODS) is a strategy combining economic development, social inclusion, and environmental sustainability as guidelines for growth which should be implemented by every developed and developing country. Various environmental publications that take into consideration both social and economic concerns with climate change receive more attention than environmental publications alone [11].

Fig. 1 shows a percentage greater than $60 \%$ which indicates that corporate governance is the issue with the greatest impact on sustainable development. It reflects the importance of decision making from the highest levels of organizations. The empowerment and representation of leadership need to take into account the possibilities for progress in meeting the objectives of sustainable development (ODS).

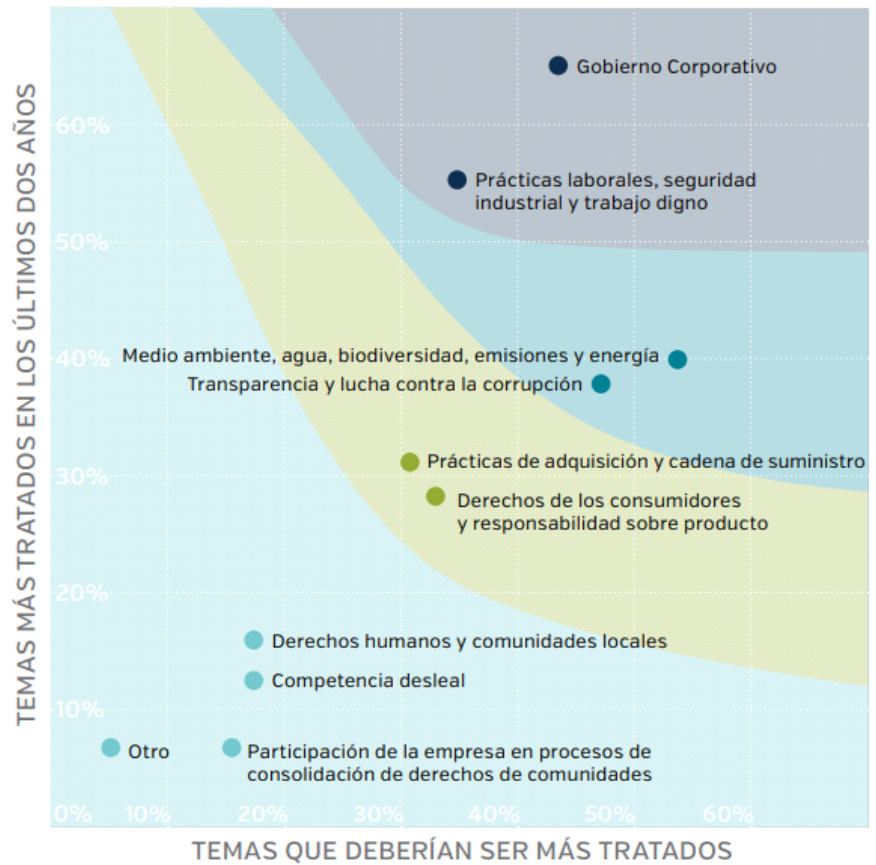

Figure 1: Results of the study question: What themes have been given more depth and what themes should be given more depth? Source: [12].

The consequences are dire and the climactic events that will loom over humanity are persistent and will continue.

The conventional focus to determine optimum mitigation routes is based on the modeled social cost of carbon which is being revised to meet new research findings. These include the economy of catastrophe risk insurance, the commercial economy and climate, and the economy of climate change adaptation [11].

In July of 2018, Colombia participated in the Paris Accord, COP24 which according to the Ministry of the Environment has a special interest in starting the battle to mitigate the impacts of climate change in Colombia. 


\section{METHODOLOGY}

A longitudinal design using group evolution (cohorts) where changes were examined over time in specific subpopulations or groups was used. Cohorts or groups of individuals linked or identified by a common characteristic such as age, time, or geographic region were used (Bell, 2009; Hsieh, 2007 and Glenn, 1977) cited by [13, p. 160].

Changes through time over these populations and specific groups in some LAC countries were measured. Therefore, changes were analyzed over time and populations and were divided into three sections. The first section was associated with a review of published articles and advances in studies. Studies on climate change variables, carbon dioxide footprint, forest area, net greenhouse gas emissions, air pollution, and populations exposed to levels exceeding WHO guidelines over a period of 18 years in Latin American countries was looked at. According to Icart and Canela (1994) cited by [14], the usefulness of the review article is multipurpose. The principal aim of this review article tries to identify what is known about the topic, what has been studied, and what aspects remain unknown. For this reason, a descriptive review of the literature was necessary.

The second section was a performance evaluation on the Objectives of Sustainable Development about the population over the past ten years. Its implication on good health and well-being, public policy, and poverty have affected sustainable development due to climate change as a result of a consequence from human activity.

An analysis of indicators of sustainable development goals in Latin American countries which include quality of life indicators, such as Social Progress Index (SPI), Human Development Index, (HDI) unemployment, poverty rates, and incidence of multidimensional poverty in some countries of LAC were taken into consideration.

The third section was a review of food security, imported food products, and the GNI Index of some Latin American countries. This review included a wide array of documents from different perspectives and sources including academic literature and databases.

\section{IV.RESULTS}

\section{a) Impact of Climate Change}

The challenge with sustainability is that as of this moment humans are using 1.6 Earth's worth of resources to survive. The Global Impulse Policy, is a national policy which aims to help local businesses take measures to reduce their carbon footprint. A carbon footprint is the measurement of greenhouse gases that are considered to be contaminating the environment.

Greenhouse gases include carbon dioxide (CO2), methane (CH4), and nitrous oxide (N2O) among others [15].

The principle causes of climate change have been the combustion of fossil fuels and changes in land use resulting in the release of carbon dioxide $(\mathrm{CO} 2)$ and other greenhouse gases since the industrial revolution in the 18th century.

Climate change is associated with the production and unsustainable consumption of goods which are dependent on the use of fossil fuels with large amounts of carbon emissions. In Colombia, IDEAM registered that the greenhouse gases: carbon dioxide, methane, and nitrous oxide were increasing from 2008-2010 as shown in Fig. 2.

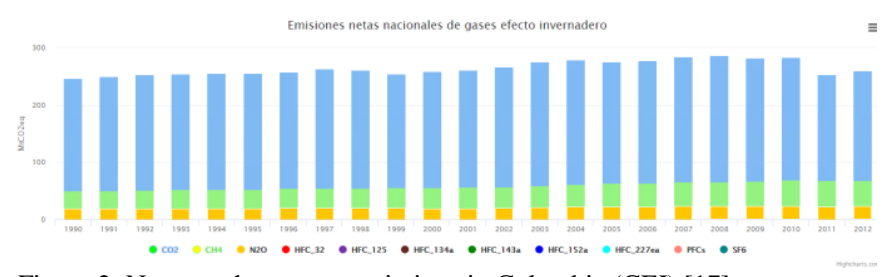

Figure 2: Net greenhouse gas emissions in Colombia (GEI) [17]. Source: Own elaboration.

Anthropogenic climate change caused by greenhouse gas emissions is easily visible in the natural environment. One consequence of climate change is an increase in the global mean surface temperature. This increase in surface temperature will cause changes in the water cycle leading to more severe climactic events [16].

Ideam [17] suggested definition is that climate change is a statistical variation in the average state of the climate which continues throughout a prolonged period. Climate change can occur due to natural processes, outside changes, or from persistent changes.

The excessive dependence on raw materials and the degradation of the environment has manifested in human health, air pollution, and the stability of ecosystems. Approximately $92 \%$ of the world's population live in a place where the air quality is below established levels. In Latin America, the country with the lowest air pollution is Argentina while Peru and Colombia (Fig. 3) have the highest levels of air pollution. Air pollution also increases the risk of acute respiratory infections. 


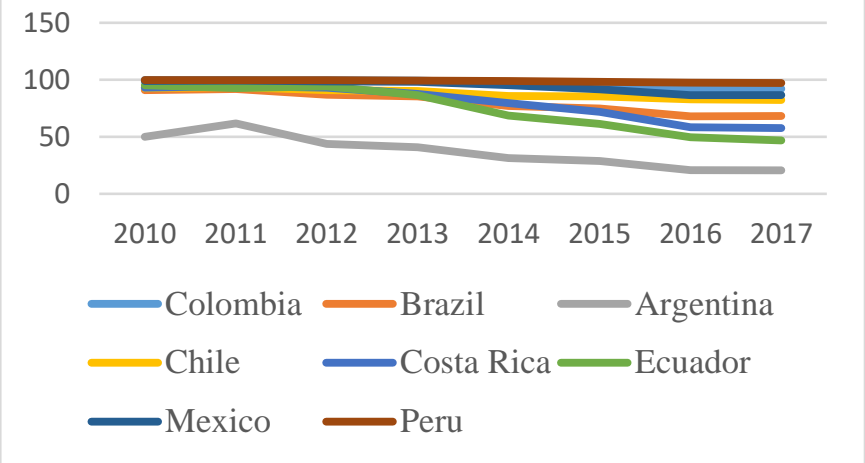

Figure 3: Population exposed to air pollution levels exceeding WHO guidelines (\% of total). Source: [20].

Ecuador and Mexico have been some of the countries with the highest emissions of carbon dioxide, from 2010 to 2014 . Countries with fewer emotions in these years include Costa Rica and Colombia (fig. 4). However, climate change will radically affect the water supply and the frequency with which forest fires occur. Increases in GHG emissions have been strongly linked as the result of economic growth for many LAC countries [18].

The emissions that are released into the air continue to change leading to air pollution, climate change, stratospheric ozone depletion, and exposure to persistent, bioaccumulative chemicals and toxins [18].

In the 1970's some were already advocating for an "adaptation" of society to climate change instead of expensive methods to reduce greenhouse gas emissions. Today behind the curtains, the reality is that the climate is changing and ecosystems are losing their balance leading to a decrease in acceptable conditions for human life on earth [19].

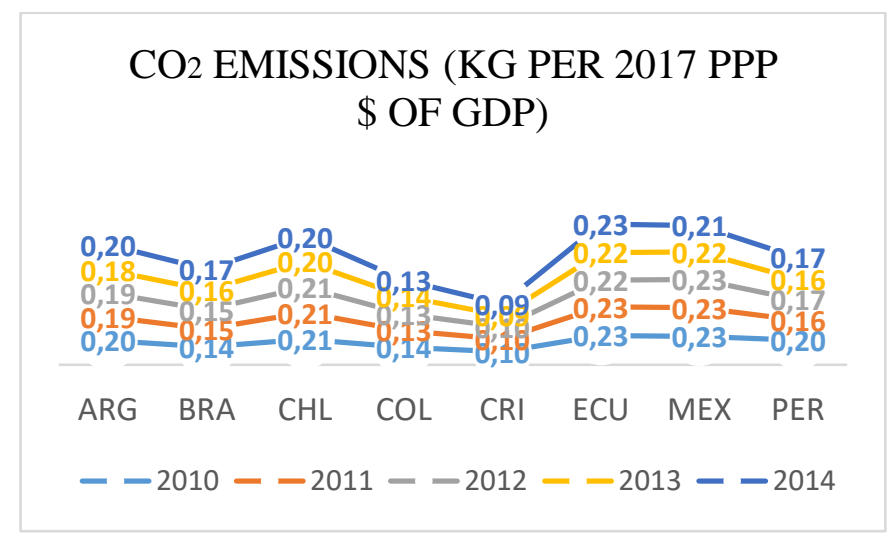

Figure 4: CO2 emissions (Kg per 2017 ppp) [20].

Source: Own elaboration.

The damages caused by climate change are generalized but in certain conditions they can surprise. In the event of a storm it can knock down buildings, cause floods, fires, and injure people. This same phenomenon can also cause various forms of respiratory diseases in human beings.

High temperatures can cause problems through water stress which can affect a large number of important crops. Mild winters can protect certain pests in their survival which affect productive yields. Global warming has become an unprecedented challenge and efforts to limit greenhouse gas emissions has been a constant one at numerous meetings of scientists, environmental activists, and politicians that started in Toronto in 1988 with an initiative to work for a changing atmosphere.

Today progress has been made and there are reasons for success: "prior talks between America and China; skillful French diplomacy; canny negotiation by developing countries. Perhaps the most important one, though, was that the cost of renewable energy was tumbling and investments in the field booming. Reducing emissions while continuing high-energy lifestyles felt newly possible" [21].

\section{b) Carbon Dioxide Footprint}

The greenhouse gases known as GEI, especially carbon dioxide (CO2) is the known gas responsible for preventing heat from escaping into the lower layers of the atmosphere. This prevents sunlight leaving the atmosphere, causing an increase in global temperature.

The measurement of carbon footprint is a pertinent way to understand greenhouse gas emissions and their effect. Businesses can use this footprint to implement internal and external ways of mitigating the consequences of climate change. Regulations such as the maintaining the cost of carbon, can help create incentives for change.

Levels of carbon dioxide in the air are greater than they have ever been in the last 650,000 years signifying that climate change is a real threat. This reveals the quantity of greenhouse gases produced daily with the possibility to increase significantly. 
Fig. 5 compares the average emissions of metric tons in countries OECD and some countries in particular. Argentina and Mexico are the countries with the highest $\mathrm{CO} 2$ emissions according to data from the World Bank which is one of the most significant influences on climate change.

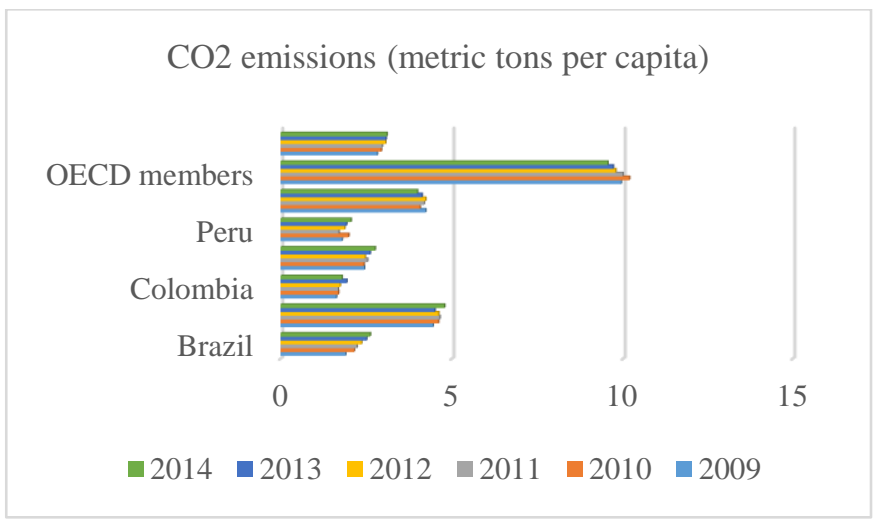

Figure 5: Evolution of carbon dioxide levels in recent years in LAC. Source: [20].

The ability of a society to have access renewable clean energy is beneficial for society while the use of fossil fuels and population growth increases the risks of climate change and environmental degradation.

Regulating energy is a way to find an equilibrium for the energy needs of society, however it does not guarantee a better quality of life.

The degradation of the environment and the atmosphere, together with the considerable decline of biodiversity, are linked to other developmental related problems such as the reduction of water and food supplies, to loss of livelihoods, and loss of life. This extremely serious crisis threatens the future of human development for current and future generations [22].

According to the report from the United Nations Environmental Program, limiting temperature rise to below $2^{\circ} \mathrm{C}$ will be impossible as greenhouse gas emissions are $14 \%$ above where they need to be in 2020 . Understanding CO2 emissions provides the ability to make smarter decisions about policies. As a consequence, better international cooperation between developed and developing countries will become paramount.

In the case of Colombia, the certification process is managed by Colombian Institute of Criteria and Certifications (ICONTEC). They are responsible for the validity and certification of greenhouse gas emissions and certification of all methods related to climate change known internationally including ISO/TS 14067:2013. This is particularly important because it establishes the requirements and methods for the quantification of the carbon footprints of products based on their emissions and greenhouse gases produced during its shelf life [15, p. 280).

The temperature has increased in all the countries analyzed with greater intensity since 2015. Mexico and Brazil have temperatures above 1.0 degrees Celsius as seen in (Fig. 6).

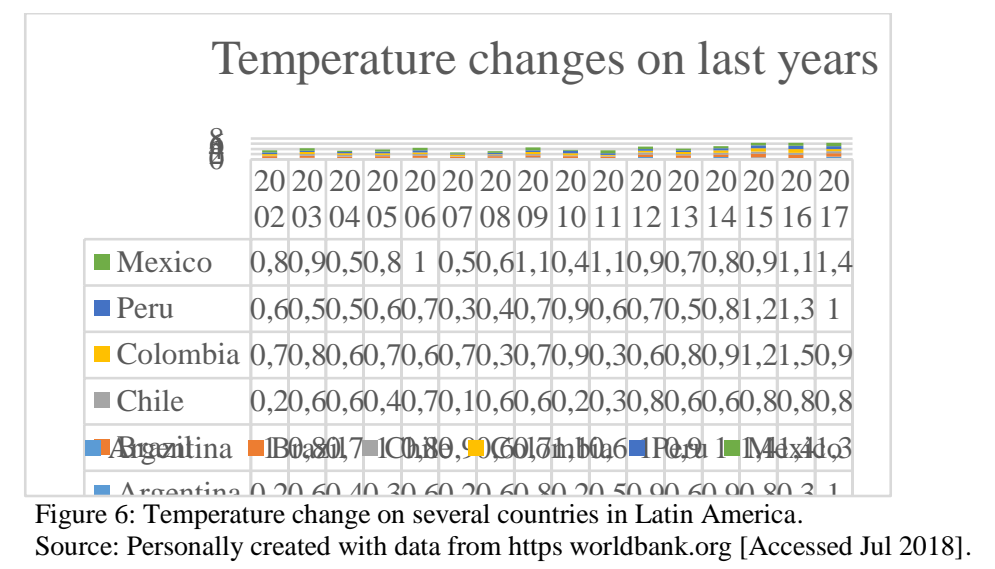

The average temperature and precipitation, as well as the maximums and minimums, have been modified. There is a variation on recent years especially for countries like Colombia, Mexico, Peru, and Brazil in 2016. 


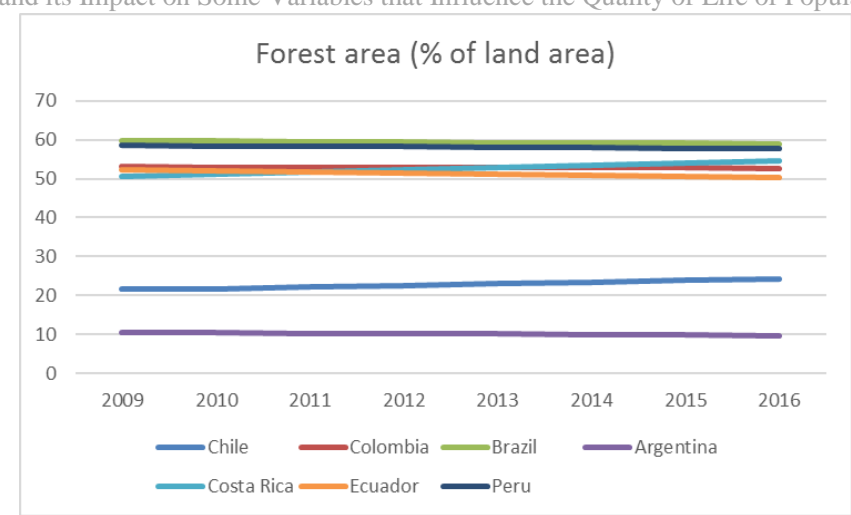

Figure 7: Forest area.

Source: Personally created with data from https worldbank.org [Accessed Jul 2018].

The highest amount of forest plantations was found in South America where this type of forest represents $99 \%$ of the total area of planted forest and 2 percent of total forest area. Brazil and Peru have the highest percentage planted with Argentina the lowest (Fig. 7).

\section{c) Sustainability Reports}

Sustainability reports can help support the objectives of sustainable development (ODS). The 17 objectives of sustainable development were universally adopted by all member states of the United Nations in 2015 in order to guide them. They present a practical way to confront global sustainability where large and small companies coexist.

These objectives include eradicating poverty, limiting inequality, protecting the planet, peace, and prosperity for all. Each objective has specific objectives which should be met in the next 12 years for the 2030 Agenda. Companies play an important role in helping to create political dialogue in order to reach the objectives of sustainable development. This dialogue includes gender equality, responsible inclusive employment, climate change, and helping to invest in environmental responsibility.

The Sustainable Goals Development Fund (SDG Fund) is an International development mechanism of multiple donors and agencies created in 2014 by the United Nations. This fund was created to help sustainable development through various programs. The "footprint material" of an economy is the amount of raw materials extracted worldwide in order to satisfy the needs, demands, and consumption in the world economy. The "footprint material" per capita of developing countries rose by 5 metric tons in 2000 and 9 metric tons in 2017.

When companies develop a conscience of sustainability, this results in various positive changes. Organizations with leaders who concentrate information into better practices are recognized by other organizations and consumers. Businesses can also help governments to create a conscience of sustainability for consumers and citizens utilizing themes of sustainability.

This represents a significant increase in the quality of life. It is important note that a large portion of climate change in the form of carbon dioxide comes from the consumption of goods. This signifies that emissions belong to the country that is the consumer of the final product. Developed countries have more of a responsibility due to their higher consumption [23].

The index of objectives of sustainable development describes how each country can meet its goals for the objective and indicate which areas require more work. These points can be interpreted as a percentage of achievement.

To achieve the Sustainable Development Goals an urgent decoupling of environmental degradation and use of resource in economic growth.

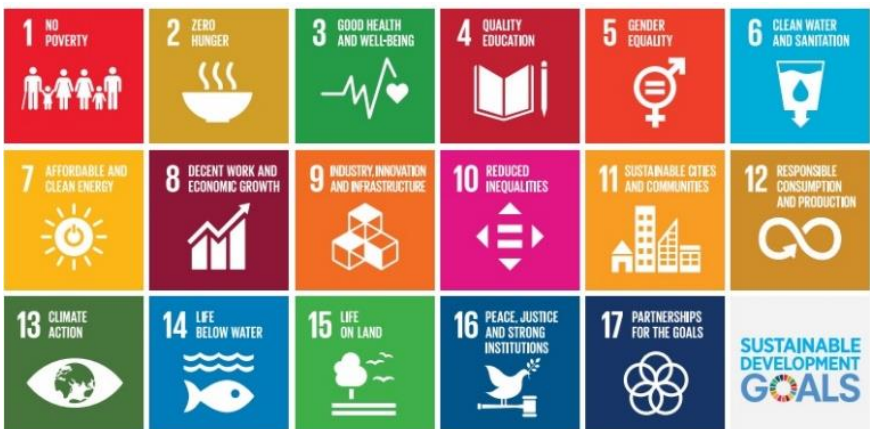

Figure 8: Objectives of Sustainable Development (ODS) [23].

Source: Own elaboration.

The objectives of sustainable development are practical to deal with global sustainability and make it proportional for all businesses big or small. Regardless of size everyone has a key role to play in the accomplishing these objectives.

These objectives offer a vision into a future which is sustainable and provides a plan of action for the main difficulties of sustainability today. These difficulties include climate change, water scarcity, food security, contamination, inequality, human rights, and urbanization among others. Biological diversity refers to the different and differences of living beings at the genetic, species, and ecosystem levels. They help regulate the climate, filter the air and water, makeup the soil, and mitigate the effects of natural disasters [8, p. 11]. 


\section{d) Objectives of Sustainable Development in Latin America}

The SDG index can help identify the objectives of sustainable development and their function as a long-term guide for national policies and strategies for sustainable development. It allows for the comparison of countries with different developmental rates, but also allows countries to compare themselves utilizing a holistic method in order to meet the objectives of sustainable development.

Sustainable Development Goals (SDG 10) for reducing inequality and (SDG 16) for Justices of the peace and sound institutions represent some of the most important challenges for Latin America and the Caribbean. Some countries also worry about the persistent challenges related to (SDG 3) which include having good health and well-being, (SDG 9) industry, innovation, infrastructure, and (SDG 14) ocean/marine conservation.

Fig. 9 shows how health coverage declined in each one the countries analyzed, especially in 2018 and especially in Argentina and Mexico. In 2019, only Chile reached a coverage of 70 percent. The access to healthcare is determined primarily by political systems, economic, environmental, and social policies that go beyond the direct influence of the health sector and shape the conditions of daily life.

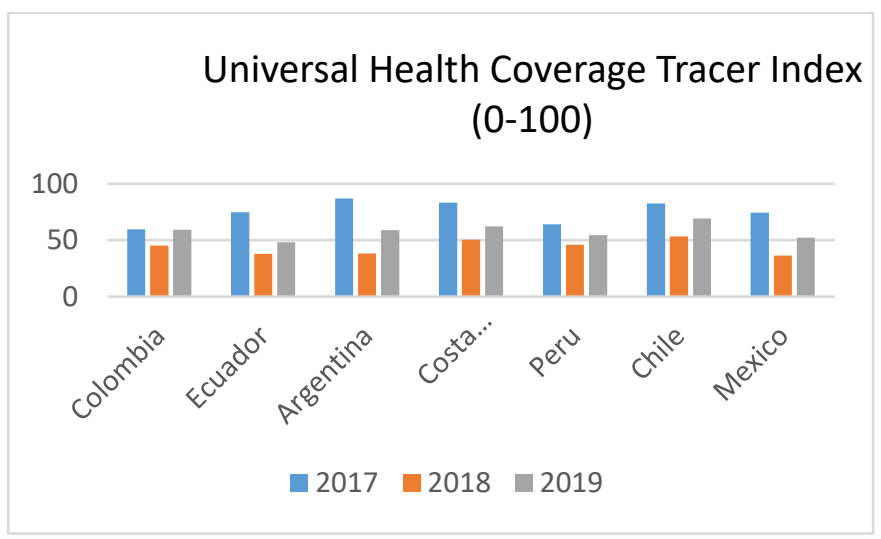

Figure 9: Goal 3 Good Health and Well-Being.

Source: [24].

Regarding governments, they are using the Sustainable Development Objectives in order to create new policies and regulations. Companies that recognize and compromise to meet the Sustainable Development Objectives will have business models more resistant to emerging problems. Sustainable development represents a historic opportunity for businesses to profoundly change the way objectives of sustainable development were met through innovation.

It is urgent to begin the transition to sustainability. Society depends on the responsible management of natural resources in order to preserve ecosystems and biodiversity. This management will lead to the sustainability of food production, clean water, air, and the raw materials needed for sustainable economic growth.

This will lead to the opportunity for businesses to create a market for goods and services according to the model of sustainable development and help the future of their company.

National political regulations and requirements have clear implications for the business sector, especially for multinationals that depend on global supply chains. This domino effect assures that regulations affect small and large businesses equally (PYMES). It is probable that businesses that compromise with a strategy plan with national priorities will receive a license to operate on behalf of the government and its citizens. Those businesses that do not compromise will be at a significant competitive disadvantage.

Internet and social media users are the ones who lead the way in helping to inform users, visualize environmental issues, and are more open to the use of new technologies.

However, population growth, agricultural intensification, urbanization, and industrial growth are creating a competition for natural resources such as land and water. Excess use will inevitably lead to environmental degradation.

\section{e) Public Policy and Poverty}

\section{1) Poverty}

The first goal of the Sustainable Development Goals (SDGs) is to end poverty in every form it comes in. The global MPI 2019 created a tool which allows the ability to fight poverty.

The coronavirus (COVID-19) crisis is unlike any crisis ever faced in recent memory. The potential social and economic impacts have the potential to place approximately 49 million people into extreme poverty in 2020 [25, par. 1].

This attention is currently focused on concepts such as "need", "standard of living", or "insufficient resources", that is, it has a broader concept, understood as the refusal to live a long, healthy, and prosperous life.

To according [26, par. 9] this is described as the inability to enjoy a decent level of life, freedom, dignity, and respect for oneself and for others. Additionally, malnutrition impacts almost a third of the world and almost half struggle with more than one type of malnutrition. There 
are extremely serious economic complications for developing countries, especially those whose people face more than one type of malnutrition, including undernutrition and obesity.

With few exceptions, progress has been made in the eradication of extreme poverty, improved healthcare, and gender equality in the region. On the other hand, countries which work towards (SDG 13) climate change action, are often hindered with this objective.

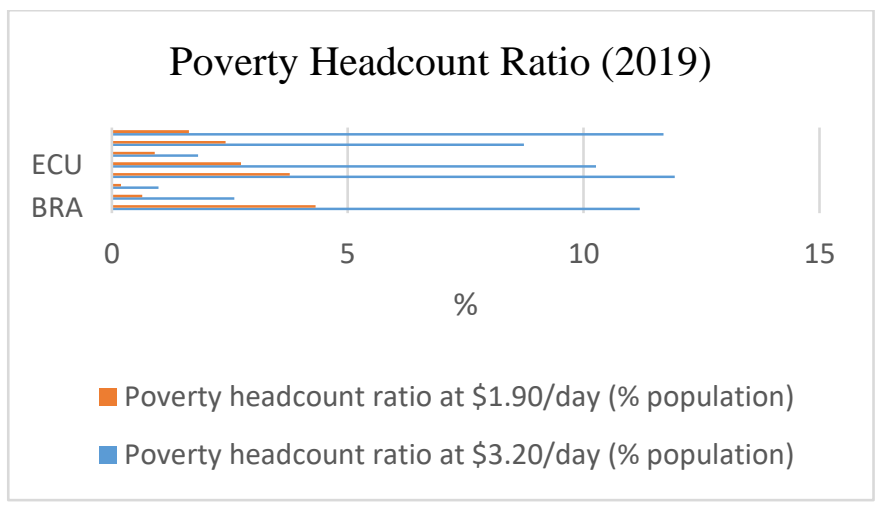

Figure 10: Poverty headcount ratio at $\$ 1.90 /$ day and $\$ 3.20 /$ day (\% population).

Source: Personally created with data from Sustainable Development Database (2020).

Fig. 10 shows that Colombia is one of the countries with a low score compared with other countries in the region regarding this variable, which indicates that multidimensional poverty increased in three years and has divergent levels among others countries in Latin America. Previously, poverty was understood as a lack of enough income to overcome it. Poverty rates in rural areas around the world is $17.2 \%$ which is 3 times more than urban areas [24].

The COVID-19 pandemic is unprecedented in terms of its pressure on healthcare. Its impact on society and the economy will have varying effects for each country but will generally impact poverty rates and increase inequality making achieving SDGs even more urgent [27]. In times of crisis and market uncertainty, there are changes in demand, especially in the most vulnerable segments of the population.

In recent times there has been an accelerated transformation of society towards a variety of changing aspects of inequality. Segments of the population that once had shortages now have opportunities for wealth, but new realities of poverty and difficulties for daily survival have emerged.

Undoubtedly, this health crisis will increase the deprivation of the population with the extreme poverty that it has suffered in terms of barriers to access to health services, access to drinking water, among other indicators in countries such as Colombia among others.

The globalization and the internationalization of economies, as well as profound transformations in social, productive, environmental, and technological factors has had an interesting impact on public policy. Responding to the philosophy of social welfare is a taboo because it remains politically unacceptable, but privately necessary. This does not allow it to respond to these new challenges with fluidity, but rather in weak and inoperative ways which do not have the agility to give them adequate responses to new problems.

Globally, income inequality is what most contributes to global inequality, followed by education and life expectancy [22].

The complex efforts of countries and organizations have allowed achievements and challenges aimed at the implementation of transference conditions (PTC). These programs allow for the construction of social protection systems in Latin America, which give light to public policies to fight poverty.

The Latin American PCT models, which appeared in the mid-nineties focused not only on the model of social protection systems and contributions, but went further in their introduction of universal social rights which are related to citizenship and other important aspects shared by beneficiaries. This created the objective of improving levels of health, education, nutrition, and strengthening human capital. The application of public policies and the intervention in economic and social development has been achieved largely due to democratic institutions.

Tassara [28, p. 326] affirms:

(...) Organizations such as the World Bank, the Inter-American Development Bank (IDB), United Nations Development Program (UNDP), the Economic Commission for Latin America and the Caribbean (ECLAC), and the European Union have played a proactive role in the promotion of new paradigms in the fight against poverty. This has stimulated greater attention towards approaches based on social cohesion, citizenship, and social-political rights.

According to [29], the poverty rate is the proportion of the number of people (in a given age group) whose income falls below the poverty line; taken as half of the average household income of the total population. It is also established by age group: child poverty (0-17 years), working-age poverty, and old-age poverty (66 years or more).

Economic growth has recently benefited the wealthy more than the poor. This gap has also grown between the rich and the middle class. While salaries have improved for those who are already well paid, employment rates have fallen among people with less education. Low-income individuals have been hampered from realizing their human capital potential, which also hampers the economy. 
Between 2002 and 2014, the Latin American region grew at an average rate of 3.32\% per year, while addressing public policies on social issues. The combination of these factors had an important effect on welfare, as the number of poor people went from 233 million to 168 million while the number of impoverished people went from 63 million to 48 million. However, since 2015, there has been an increase in the general levels of poverty and extreme poverty. In 2017, more than 187 million people were still living in poverty and 62 million were living in extreme poverty.

These figures are a signal regarding the capacity of the region to comply with Goal 1, which aims to put an end to poverty in all its forms and throughout the world. The Multidimensional Poverty Index (MPI) is a measurement to help monitor the progress towards the most difficult goal and first objective of sustainable development (ODS). With goals established for 2030 which includes the elimination of both monetary and multidimensional poverty.

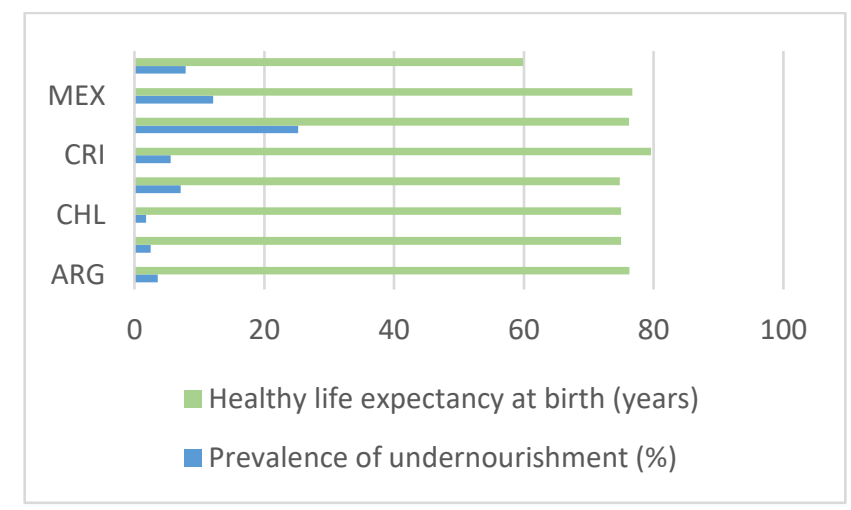

Figure 11: Population in multidimensional poverty year 2018.

Source: [23].

In 2018 (Fig. 11) a high prevalence of malnutrition is observed in the population of Ecuador and Mexico and to a lesser extent Peru and Colombia. The lowest percentage of malnutrition is in Costa Rica. Within Fig. 11, the life expectancy at birth shows that there are lower life expectancies of birth in Peru. The life expectancy is less than 60 years while in Costa Rica it is approximately 80 years.

Close to 40 million people ( $8 \%$ population in the region) live in multidimensional poverty and 11 million (2\%) live in severe multidimensional poverty. At the same time, 39 million people were identified as vulnerable to multidimensional poverty. This shows a significant number of people in the region have a high probability of falling into multidimensional poverty if any type adverse shock affects their country or home. These kinds of vulnerabilities reinforce the idea that although Latin America and the Caribbean is indeed a middleincome region, it's still far from being a middle-class society [30]. Despite the progress made in human development, there are still deprivations in all countries. The Multidimensional Poverty Index (MPI) reflects these deprivations in mainly developing countries since 2010.

In the context of objectives of sustainable development (ODS) of the 2030 Agenda elimination of poverty in monetary and multidimensional terms helps to promote the evaluation of progress in reaching the "IPM-global" goal. Countries such as Denmark, Finland, and the Czech Republic have the lowest poverty ranking worldwide.

In comparison Latin America and the Caribbean are furthering themselves from completing the zero-hunger objective. The number of people undernourished rose for the third consecutive year affecting 39.3 million people or $6.1 \%$ of the population. This problem increased throughout South America as well with food insecurity increasing when compared to the previous year unproportionally affecting more women than men [31].

The trend that there is more poverty in rural areas has not changed in the past 20 years. Jaramillo [32] argues that since a high percentage of the population living in poverty live in rural areas, strategies must be considered to solve the problem for the people who live in these remote areas. "It is necessary to address this problem by highlighting its multidimensionality and heterogeneity. Trying to implement proposed solutions within the approaches that tend to help the entire population".

Fig. 12 shows a range of people emerging from multidimensional poverty since 2010 , which has decreased steadily over the past 8 years. However, the multidimensional poverty that affects people in a greater proportion is localized in villages and rural areas.

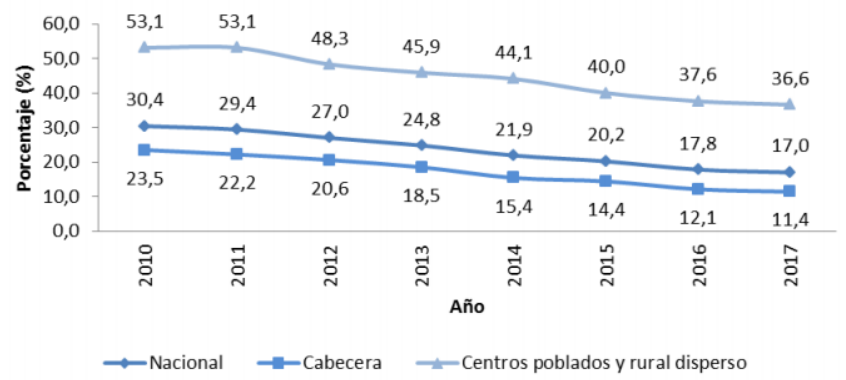

Figure 12: National total of Poverty in Colombia in head towns and dispersed rural centers. Source: Taken from Dane (2017) National Survey of Quality of Life. Colombia. 
After a decade of reduction in poverty, rates of poverty and homelessness have been increasing since 2014 . In 2016 they reached $26.8 \%$ and $7.2 \%$ respectively among Latin American countries [33].

Even though extreme poverty has considerably declined since 1990, pockets of the worst forms of poverty persist. Ending poverty requires social safety nets which help people throughout their life. These safety nets must also include measures to reduce vulnerability to disasters and to address specific underserved geographic regions within each country [34].

On the other hand, it should be said that social mobility is higher in countries where income inequalities are relatively low. This statement is evident in the case of Venezuela, Honduras, and Nicaragua with one of the largest migrations in recent years. Inequality in any country and a truly sustainable economy respects the basic rights of all people in all countries. The consequence of bad governments coupled with climate change is a serious threat to global development and efforts to end poverty. Without urgent action over 100 million people could be forced into poverty by 2030 . Immediate action is needed to reduce the threat and impact of climate change.

In terms of population sensitivity to climate change, poverty and inequality are the factors that most significantly contribute to this variable. This situation is particularly serious in Mesoamerica, where rural territories are highly dependent on subsistence agriculture, which is marginal and poorly qualified [35].

Countries with greater ranges of poverty, produce human rights problems such as child labor. This is due to the lack of decent work opportunities for adults, social norms, migration, and emergencies. A new World Bank report shows that climate change is a serious threat to the poorest people around the world. The poorest regions of the world which include Sub-Saharan Africa and South Asia, will be the most affected [36]. Ending poverty will not be possible without accounting for and managing policies to reduce poverty.

Public policy models have suggested that increasing income inequality will lead to more redistributive spending. However, subsequent theoretical advances and empirical research has failed to find a positive relationship between inequality and redistributive spending. In recent decades, both income inequality and redistributive spending have increased in countries such as the United States [37].

The reduction of agricultural productivity is already happening. It is not only limited to corn, but in the larger foods involved in basic food production, such as sesame, sorghum, beans, rice, and coffee among others. In the same way, the proliferation of pests and diseases are evident and resistant in the aforementioned crops. (Morales and Zúñiga, 2016, p. 17).

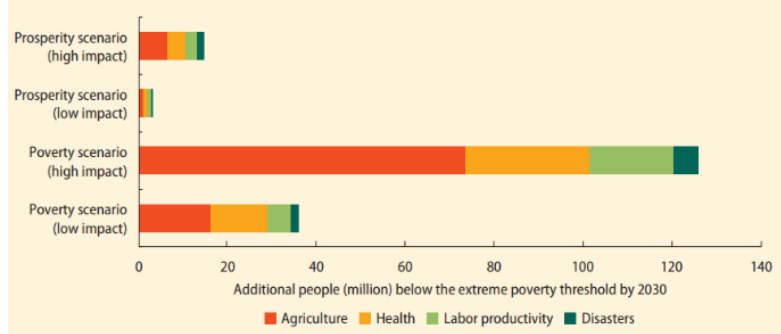

Figure 13: Prospective of several variables as the main sector driver, explaining greater poverty due to climate change [38].

Source: Own elaboration

The desertification and degradation of agricultural land creates problems within various economies of the region (in terms of products and labor) while having a significant impact on the resilience of farming economies with low revenues which augments the poverty and vulnerability of society [33].

In figure 13, there are 4 scenarios which are affected by global warming. They include: agriculture, health, natural disasters, and productivity. A scenario with a high impact of global warming on ecosystems will affect agriculture and other variables to a greater extent. Therefore, the level of poverty will dramatically increase between 70-80 million people under the extreme poverty limit for the year 2030 . In a possible prosperity scenario, the variables are affected to a lesser extent.

According to [39]:

Climate change is an unstoppable phenomenon and the sooner appropriate measures are taken the faster society can adapt and counteract its negative effects. Adaptation is equal to or almost more important than mitigation. Adaptation of agricultural production systems to new scenarios must be considered as a priority, and those who are able to adapt faster and better will be more sustainable and more competitive.

After a prolonged decrease, hunger in the world seems to be increasing again. Conflict, drought, and disasters related to climate change are some of the key factors that cause this ongoing reversal. Agriculture accounts for almost 70 percent of the world's water use which will increase in the near future.

Social protection systems help prevent and reduce poverty and provide a safety net for the vulnerable. However, social protection is not a reality for a large majority of the world's population. In $2016,55 \%$ or 4 billion people were not covered by any social protection cash benefits, with large variations across regions [24].

\section{f) Quality of Life Indicators}

Quality of life indicators utilize several different variables to explain the quality of life at a particular level of society. This are measurable, and available for most countries. 
Gross domestic product (GDP) per capita (current US \$), is not a good measure of income distribution in society. Some countries have a high GDP per capita, yet have many living in poverty. There is also the years of schooling of mothers (MYS) (years) - Gross national income (PPP, GNI) per capita (US \$ at current prices) among others. Environmental indicators can be grouped on the basis of their relationships with quality of life in the following categories: environmental quality, environmentally responsible behavior, and consumption of environmental services. These groups are tightly interrelated because responsible behavior has a positive impact on environmental quality, which leads to a higher consumption of services provided by the environment [40].

\section{Social progress index}

The Social Progress Index (SPI) is the first comprehensive model to measure the performance of companies that does not include the Gross Domestic Product (GDP) or other economic variables. It was conceived by the Council on Philanthropy and Social Investment at the World Economic Forum in Davos in 2009.

This index provides a robust and holistic framework for measuring social and environmental performance that can be used by government leaders, the private sector, and civil society as a parameter of success to catalyze progress [41].

The Social Progress Index aims to be a practical tool that helps leaders and professionals from the government, the private sector, and civil society to implement policies and programs that promote faster social progress. These countries stand out from the rest of the countries in the region that demonstrate an action strategy within their social investment policies. This strengthens their capacity to influence the decisions of public and private entities in order to strategically mobilize the resources of social investment based on the analyzed variables.

To help monitor poverty, inequality, and the empowerment of women in multiple dimensions of human development, four additional composite indices have also been developed: The Multidimensional Poverty Index (WPI), the Human Development Index adjusted by Inequality (IDH-D), the Gender Development Index [22] and the Gender Inequality Index.

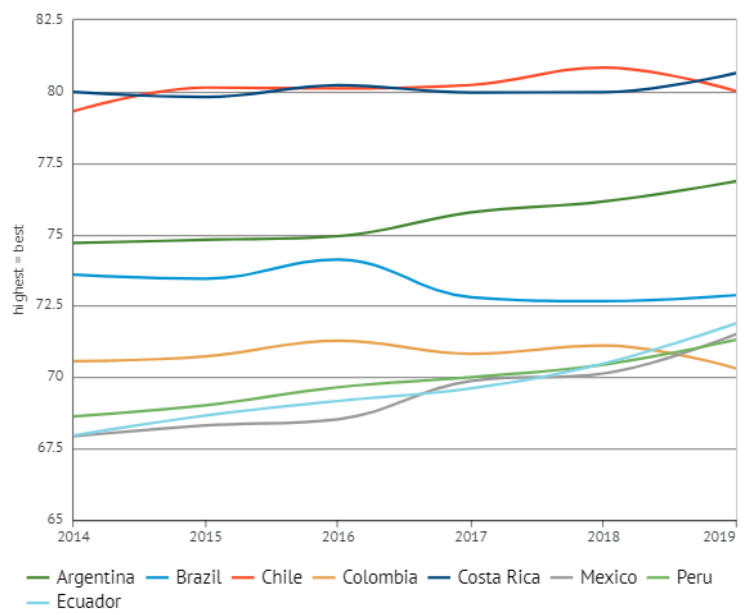

Figure 14: Social Progress Index in countries of Latina America. Source: Taken from socialprogress.org/.

According to the Social Progress Index [42], the countries with the highest rate of social progress in Latin America are Costa Rica, Chile y Argentina.

The objective was to provide a solid and holistic social and environmental performance measurement framework that could be used by government leaders, the private sector, and civil society as a success parameter to measure progress. The National Index of Social Progress (NISP) allows the capture of social prosperity at the national and departmental level with up-to-date data, monitoring the achievements of public policies applied in certain components and regions, and guiding the design of new policies towards the ideas and regions that present less favorable and more urgent needs.

The Economist cites the Social Progress Index as the most elaborate measure of quality of life" and concludes that all over the world. The basic needs of people are met, but they lack opportunities. Based on figure 15 Costa Rica, Chile, and Argentina are the top countries by social progress index among 8 countries, while Colombia, Ecuador, and Mexico are the countries with the lowest score on opportunity's variable. 


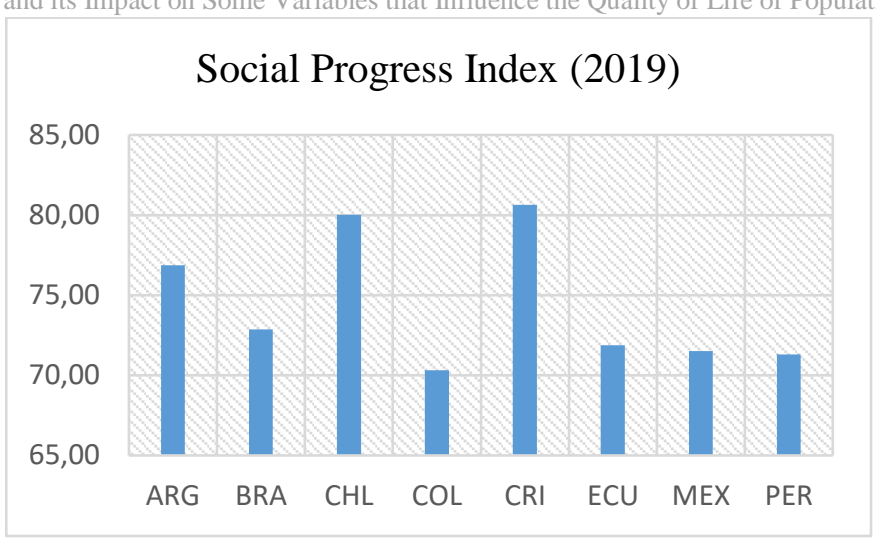

Figure 15: Social progress index (SPI) 2019.

Source: Personally created with data from https://www.socialprogress.org (2020).

The SPI is published annually by 133 countries around the world by the Social Progress Imperative. (Porter, Stern, \& Green, 2015) It proposes a holistic measurement model that is being used by government, businesses, and civil society leaders to accelerate progress towards societies with better levels of human welfare [43].

Creating opportunities for SMEs in emerging markets is key to advancing development and reducing poverty according to the International Finance Corporation. The biggest innovations in human development reports have been the new measurement tools used; specifically, the Human Development Index (HDI). National development should be measured not only by per capita income, as had been the practice for a long time, but also on achievements in health and education.

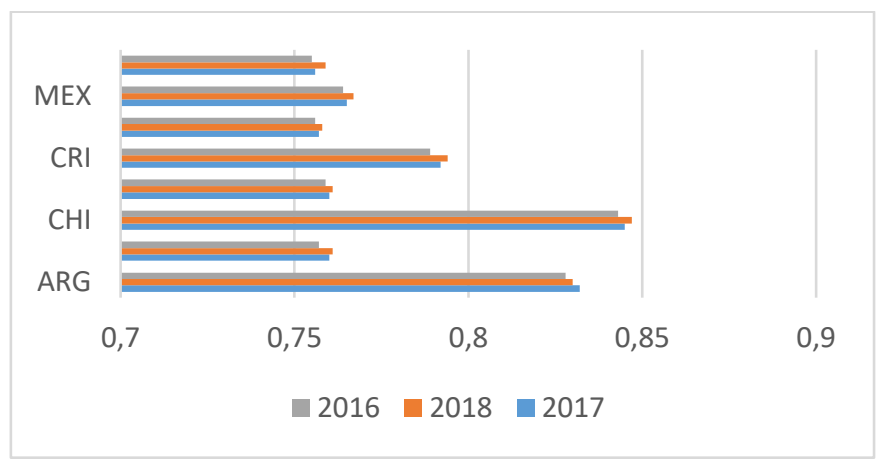

Figure 16: Human Development Index in Latin America in (2018).

Source: Personally created with data from https:// http://hdr.undp.org [Accessed Oct 2019].

Colombia is the country with the lowest social progress index between 8 countries evaluated. Evaluations and studies indicate that in Latin America, the intervention of international organizations has played an active role in the promotion of anti-poverty programs. Redistributive social policies and economic growth in Latin America have allowed poverty levels to be reduced, but efforts are still being made to overcome monetary and multidimensional poverty. This is in addition to addressing problems of social segmentation, inequality, social exclusion, and climatic aspects that are relevant.

There are huge disparities between opportunity, wealth, and power. These differences in income inequality raise social, economic, and political concerns. Gender inequality remains a great challenge, and unemployment among the youth is one of the biggest concerns. Other global threats such as natural disasters, conflict, extremism, terrorism, humanitarian crisis, and forced displacements continue to be a constant concern for the development and progress nations.

Inequalities in life expectancy at older ages represents a type of emerging inequality in the field of human development in the 21 st century. Divergences in access to knowledge and more advanced technologies are even more noticeable. In countries with very high human development, the proportion of the adult population with higher education is growing at a rate more than six times higher than in developing countries. In the case of subscriptions to fixed broadband, the growth rate is 15 times higher [1]. 


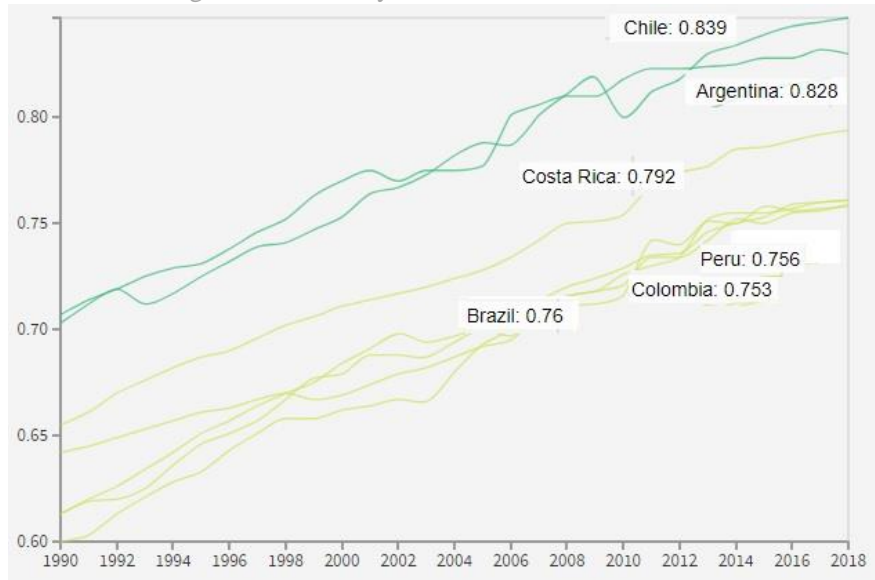

Figure 17: Index Comparisons Human Development Data (1990-2018). Source: [44].

\section{g) Food Security}

Latin America countries (18) have shown a significant increase in food insecurity (49\% to 57\%) with increases in moderate food insecurity (13\% to $16 \%$ ) and severe food insecurity (14\% to 19\%) during the most recent economic recession (2014 to 2017) [45].

According to Conpes 113 /2008 [46], food and nutrition security, is a right of each person to avoid hunger. This takes into account the international treaties adopted on various countries fundamentally based on the joint construction of different actors and agents within the nation's borders. The global impact of pandemic for COVID 19 on health can affect the workforce, transportation systems and supply chains.

The percentage of undernourished people around the world increased from 10.6 percent in 2015 to 11.0 percent in 2016 . Approximately 815 million people worldwide suffered from undernourishment in 2016 and more than 777 million in 2015. Almost 151 million children under 5 also suffered from stunting (low height for their age) while 51 million suffered from problems with physical development (low weight for height) and 38 million were overweight [47].

Increasing access to clean and healthy foods is essential to guarantee the success of future generations. The first 1,000 days of a child's life are so important that if they are fed well enough, they are $33 \%$ more likely to escape poverty as adults. Unfortunately, almost 151 million children under 5 have experienced chronic malnutrition. This poses an incredible loss of economic potential and individual freedom.

The prevalence of undernourishment is one of the main components of tracking hunger. The FIES is a measurement of food insecurity based on family/individual responses to yes/no responses to 8 questions about access to food. It uses statistical measurement to measure traits such as aptitude, intelligence, personality, psychological aspects, and health-related conditions [48].

The World Forum for Food and Agriculture, held on January 21, 2018, concluded that: "In 2050 there will be almost 10 billion people on Earth. As a result of this growth, consumer behavior will also change; "they also indicated that the agricultural sector must be prepared to change. Sustainability must become the focus of all business models, otherwise it will completely lose the market".

According to the Sustainable Development Goals Report [34] and based on the latest available data, hunger in the world seems to be increasing again. Conflicts, droughts, and disasters related to climate change are some of the key factors which are reversing progress.

The increase on the demand food will be met through increases in productivity, with moderate changes in cultivation area and in livestock herds. Improvements in yield are expected to represent $80 \%$ of the increases in crop production [49].

In the last 10 years, Argentina is one country with the lowest amounts of food imports, followed by Brazil and Chile. Countries like Peru, Mexico, and Ecuador are major food importers (Fig. 18). Despite the fact that Mexico is a major food importer, exporting countries such as Brazil is also a large importer. Brazil Argentina, and Chile are nevertheless, considered as countries with the lowest import values of food products.

\section{Import Food Products (US\$ Thousand)}

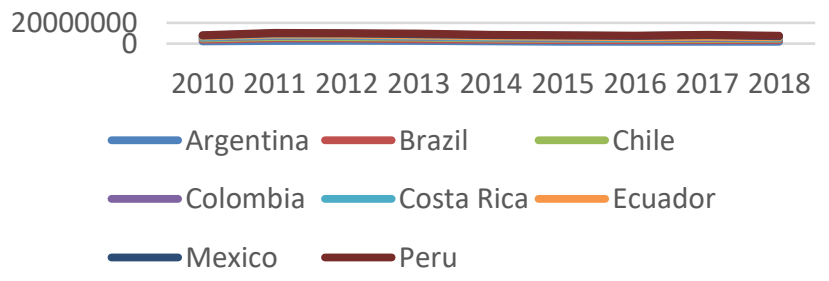

Figure 18: Import Food Products in Latin America. Source: [44]. 
Food supply is seen by the trade of the agricultural and food industry, which are interrupted to the most vulnerable populations, given the availability and acquisition for consumers who increasingly have fewer resources.

Climate change affects several different aspects of life regarding food security and nutrition. One aspect is the limited availability of food due to changes in climatic conditions which affect the production of some basic crops. High temperatures will have an influence on yields, while changes in rainfall will affect both the quality and quantity of crops.

In regions where there is water is scarcity (such as the Andean region of South America and northern Mexico), adding irrigation systems will increase the land available for farming and lead to increases in food security.

Food insecurity is typically characterized as anxiety about access to food or changes to the quality of food one consumes. This includes reducing the amount of food eaten and skipping meals entirely. Populations most at risk in most emergency situations are those that already struggling with hunger.

In Colombia, there are a variety of programs such as: "Productive territories with food security for a resilient population in peace in strategic ecosystems in Cauca". In its final draft it shows a synergy between all entity's working in the limited implementation for the completion of objectives such as resources to complete proposed activities [50].

The Global Agriculture and Food Security Program (GAFSP) strives to reduce hunger, malnutrition, and poverty by helping developing countries create more sustainable agriculture. These resources are gathered in a cost-effective way and are assigned to those who need it most using public and private investments to broaden access to financing.

Nowadays there are movements and tendencies towards the consumption of natural of organic foods. However, to mitigate with urgency and adapt to the devastating effects that climate change will have on the world, limitations in the production of such foods is necessary.

\section{h) Underemployment Rate}

In Colombia and Ecuador, the drop in the underemployment rate coincided with a reduction in the level of employment. This could indicate that those jobs were possibly eliminated, among other jobs of poor quality such as a reduced number of paid hours or insufficient income.

In Colombia, the drop in the underemployment rate coincided with a reduction the same that another countries at the level of unemployment. In Brazil the tendency increased in 2014.

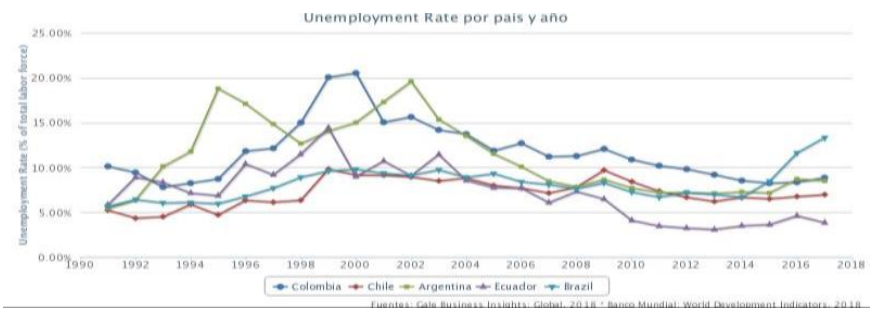

Figure 19: Unemployment range in Latin America.

Source: Personally created with data from the Gale database (2018).

This could indicate that those jobs were possibly eliminated, among other jobs of poor quality such as a reduced number of paid hours or insufficient income.

Latin America and the Caribbean suffered a new deterioration in the average quality of employment. A greater number to people are identifying themselves as self-employed which in the context of modest economic growth usually reflects precarious working conditions. Brazil, Colombia, and Uruguay are among the countries with the highest unemployment rate in Latin America.

Given that self-employment tends to be of poorer quality than salaried employment, this trend is a worrying signal regarding the challenges related to the Sustainable Development Goals (SDGs). Particularly with Objective 8, which includes full time employment ambitions and a living wage for all, among other aspects.

According to Guy Ryder (2018) director of the International Labor Organization (ILO), in qualitative terms, he affirms that the challenge facing the continent is informality. From this problem arise others such as contract outsourcing and lowering pension coverage. The rate of informality in the continent is $53 \%$, meaning that more people are working without contributing into a social security system. As a result, they do not have the same coverage and guarantees as those who do contribute to a social security system [51].

Unemployment rates affect the supply and demand of goods and services. In figure 20 high levels of unemployment were observed for Colombia in the years from 1998 to 2000 with a gradual decline which has remained stable in the last 8 years at about $10 \%$.

Argentina has experienced high unemployment rates in 2002 and has managed to reduce it $10 \%$ since 2006 . At the end of 2019 the unemployment rate in regional areas was $8.1 \%$ whereas in 2018 it was $8 \%$. Although a relatively small increase, more than 25 million people are looking for jobs for which there are none. In 2019 the amount of people considered underemployed was considered to be $19.9 \%$ and affected 66 million people [52, p. 45). Women have a higher unemployment rate compared to men in Latin American countries. The trend in unemployment could increase in post-2020 periods due to the COVID-19 pandemic if the region continues experiencing deceleration on economic growth. 


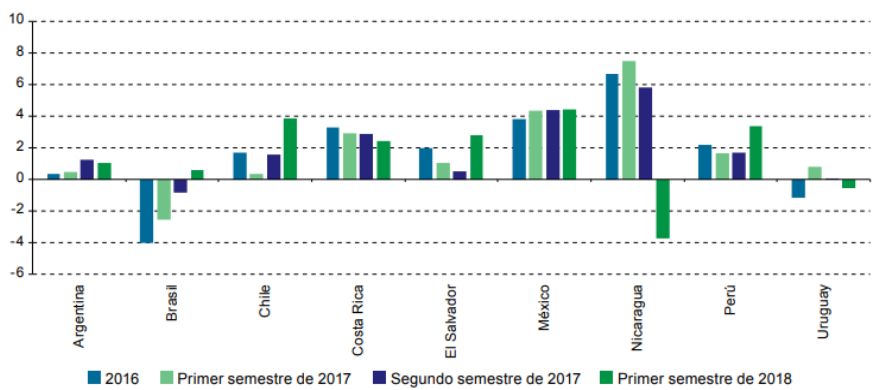

Figure 20: Taken from Interannual variation rate of registered employment in 9 Latin American countries, (2016 1st half of 2018) [51]. Source: Own elaboration.

The informal economy generates between half and three quarters of all non-agricultural employment in developing countries. Although it is not possible to generalize about the quality of informal jobs, they often imply poor working conditions and are related to an increase in poverty.

In Latin America and the Caribbean there are at least 130 million people in informal working conditions, which represents $47.7 \%$ of workers. Faced with the realization that growth alone will not solve this problem, several countries in the region have been developing initiatives to facilitate the transition to formality with the support of the International Labour Organization ILO.

The Paris Agreement, under the United Nations Framework Convention on Climate Change (2015), also includes descriptions key to the working world. The rate of urban unemployment in Latin America and the Caribbean in the first half 2018 did not show improvements throughout the year. A reduction of 0.1 percentage points was registered, due to a moderate increase in the employment rate and a slowdown in the increase in labor participation [53].

\section{i) GNI Index}

The World Bank classifies countries based on income (using US dollars): low income (GNI per capita \$1045 or less), average income low (\$1045- \$4125), high average income (\$4126-\$12,735), and high income (\$12,476 or more). Some countries in Latin America are of middle income, as East Asia, except for Japan and South Korea (high income) and North Korea (low income) [54, p. 2].

The differences in GNI per capita are of unknown cause. They reflect complex cultural, and economic interactions which are difficult to explain. These include: geographical and climatic conditions, the development of diseases, the endowment of natural resources, history, colonialism, politics, institutions, and various other causes.

Even so, Mexico City is one of the most polluted cities on the planet. The environmental Kuznets curve (EKC) argues that there is an inverted $U$ in relationship between pollution and per capita income. As economic growth increases so does environmental degradation. At a certain point greater economic growth may increase environmental benefits.

Fig. 21 shows that Mexico has the highest GNI per capita which indicates that in the last 30 years it has had the greatest development in Latin America.

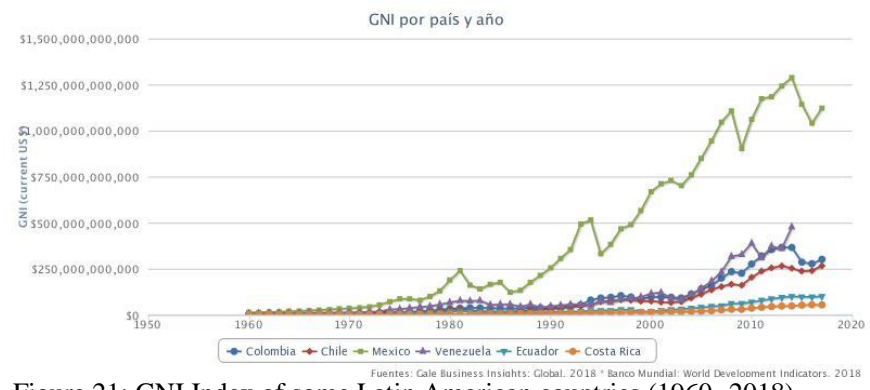

Figure 21: GNI Index of some Latin American countries (1960- 2018).

Source: Personally created with Gale Business Insights (2018).

The creation of urban waste per capita is also increasing in the region and the infrastructure needed for its recollection, use, and disposal is directly related to the primary consumer. Latin America and the Caribbean produce $1.1 \mathrm{~kg}$ of solid waste per capita per day. The amount of waste created is less than the world average but is expected to increase to $1.6 \mathrm{~kg}$ in 2025 . This increase would result in 730,000 tons of waste produced daily [35].

Even these statements contradict those set out in the last sustainable development report in 2018. The carbon footprint of developed countries are at least twice the size of developing countries. There are government programs that provide some proactive measures on a temporary basis to solve a permanent problem. Pollution requires preventive measures, not proactive ones.

Developing countries are struggling to comply with the first stage dealing with residential energy needs. Once basic needs are met focus can be turned to the industrial and transportation sector. 
The relationship between GNI and GDP highlights what amount of the GDP of a nation is due to international activity. It has also been slowly replacing GNP in international statistics.

\section{CONCLUSIONS}

This study analyzed the current impacts generated by climate change on society in various ways. These impacts on the objectives of sustainable development included food security, multidimensional poverty, and the index of social progress. These and other factors help to unite communities and demand policy changes at the national, regional, and international level.

The objectives of sustainable development try to ensure the success of peaceful countries and cultures. Peace cannot occur without sustainable development and the latter cannot occur without the former. When companies align with the Sustainable Development Goals (SDG) they will have the clarity to see how their businesses can help or hinder the achievement of sustainable objectives. Then, the government can act using public policies to create new ventures with opportunities for business growth.

The variability and extreme climate conditions have become more complex in recent years which threaten to destabilize food production and nutrition in the world. This would reverse the achievements made in the elimination of hunger and malnutrition. Imbalances persist in the precariousness of formal work in rural and urban areas in Latin American countries including in job stability, family, and food security. These difficulties only add to the insecurity of access to labor rights and social protections with guarantees.

Climate change is changing the lives of many people by experiencing scarcity in natural resources and climactic events that are becoming more extreme with increasing levels of greenhouse gas emissions. This threat is one that persists and worsens as time moves forward leaving a bleak future of life on earth. Adaptation and knowledge of climate change will be needed in order to allow production systems to find new ways of coping and systems that can meet the current demand for food.

Public policies on reducing poverty cannot be solely focused on social programs within a given population. They must also help vulnerable populations move themselves towards a sustainable and productive way of life to help generate income.

There are many conversations around the world about the responsibility humans have in the face of climate change and food security. Easy access to food is limited by climate change as it can increase prices in some regions, leading to lower agricultural production, lower incomes, and less access to food for the most vulnerable populations.

Climate variations due to climate change have brought droughts, floods, diseases, and an increase in phenomena such as El Niño and La Niña, which have been impacting food production. Due to this situation, malnutrition, famine, scarcity of food, and water have increased in various parts of the world.

Food security threats affect vulnerable populations, just as climate change brings changes in crop patterns and soil yields, which must be counteracted by promoting technologies with varieties resistant to climate change.

Countries and organizations must commit to solid and practical programs to combat poverty in order to counteract significant problems such as: climate change, natural disasters, rising health care costs, and diseases. There is a need to create elaborate public policies that have both stability and institutional continuity. They must be socially accepted and have a legal framework. This is the only way to adapt to climate change and form policies to combat poverty.

Climate change is a phenomenon that will continue, despite efforts to reduce carbon dioxide (CO2) emissions. Experts indicate that it will continue and priorities must be made to ensure who will assume the responsibility. A great deal responsibility will fall on the most developed countries while the most affected will be those living in low-income countries which have the highest poverty rate in the world.

\section{VI.REFERENCES}

[1] Programa de las Naciones Unidas para el Desarrollo (PNUD), Panorama general: Informe sobre Desarrollo Humano. Más allá del ingreso, más allá de los promedios, más allá del presente: Desigualdades del desarrollo humano en el siglo XXI. New York: PNUD, 2019.

[2] Grupo Intergubernamental de Expertos sobre el Cambio Climático (IPCC). (2012). Informe especial sobre la gestión de los riesgos de fenómenos meteorológicos extremos y desastres para mejorar la adaptación al cambio climático: Resumen para responsables de políticas [Online]. Available: https://www.ipcc.ch/site/assets/uploads/2018/03/IPCC_SREX_ES_web-1.pdf

[3] G. Rohat, J. Flacke, A. Dosio, S. Pedde, H. Dao, and M. van Maarseveen, "Influence of changes in socioeconomic and climatic conditions on future heat-related health challenges in Europe," Global and Planetary Change, vol. 172, pp. 45-59, Jan 2019. doi: https://doi.org/10.1016/j.gloplacha.2018.09.013

[4] H. L. Tuomisto, P. F. Scheelbeek, Z. Chalabi, R. Green, R. D. Smith, A. Haines, and A D. Dangour, "Effects of environmental change on agriculture, nutrition and health: A framework with a focus on fruits and vegetables," Wellcome Open Research, vol. 2, num. 21 , 2017. doi: 10.12688/wellcomeopenres. 11190.2

[5] M. M. Masud, M. N. Azam, M. Mohiuddine, H. Banna, R. Akhtar, A. S. A. Ferdous-Alam, and H. Begum, "Adaptation barriers and strategies towards climate change: Challenges in the agricultural sector", Journal of Cleaner Production, vol. 156, pp. 698-706, Jul 2017. doi: https://doi.org/10.1016/j.jclepro.2017.04.060

[6] Environmental Protection Agency (EPA), The effect of climate change on water resources and programs [Online]. 2010. Available: https://cfpub.epa.gov/watertrain/pdf/modules/Climate_Change_Module.pdf

[7] D. González Zeas, B. Erazo, P. Lloret, B. de Bièvre, S. Steinschneider, and O. Dangles, "Linking global climate change to local water availability: Limitations and prospects for a tropical mountain watershed," Sci Total Environ, 24; 650(Pt 2), pp. 2577-2586, Feb 2019. doi: 1016/j.scitotenv.2018.09.309 
[8] Programa de las Naciones Unidas para el Medio Ambiente (PNUMA), Perspectivas del medio ambiente mundial GEO 6: Resumen para responsables de formular políticas $\quad$ [Online]. $2019 . \quad$ Available: https://www.fuhem.es/media/cdv/file/biblioteca/LecturasRecomendadas/2019/GEO6Resumen-red.pdf

[9] B. Feld, and S. Galiani. (2015, May 29). Climate Change in Latin America and the Caribbean: Policy Options and Research Priorities [Online]. doi: 10.2139/ssrn.2611954. 2015

[10] International Trade Centre (ITC), The State of Sustainable Markets: Statistics and Emerging Trends. Geneve: ITC, 2017.

[11] A. Enríquez de Salamanca, R. Díaz Sierra, R. M. Martín Aranda, and M. J. Santos, "Environmental Impacts of Climate Change Adaptation," Environmental Impact Assessment Review, vol. 64, pp. 87-96, May 2017. doi: https://doi.org/10.1016/j.eiar.2017.03.005

[12] C. E. Piedrahíta, A. Pradilla, E. Sanín, A. Mejía-Zurek, D. Kiron, C. Murcia-Alejo y D. L. Caro-Borbón. (2016, Sep.). Direccionando la sostenibilidad desde el directorio: El caso latinoamericano [Online]. Available: https://www.globalreporting.org/resourcelibrary/Direccionando\%20la\%20Sostenibilidad\%20desde\%20el\%20Directorio.pdf

[13] R. Hernández-Sampieri, C. Fernández-Collado, and P. Baptista-Lucio, Metodología de la investigación. 6th ed. México: McGraw-Hill, 2014.

[14] J. A. Guirao-Goris, A. Olmedo-Salas y E. Ferrer-Ferrandis, "El artículo de revisión,” Revista Iberoamericana de Enfermería Comunitaria, 1, 1, 6, 2008 [Online]. Available: https://www.cobico.com.ar/wp-content/archivos/2016/08/el_articulo_de_revision.pdf

[15] I. Chacón-Páez, A. C. Pinzón-Vargas, L. Ortegón-Cortázar y S. P. Rojas-Berrío, "Alcance y gestión de la huella de carbono como elemento dinamizador del branding por parte de empresas que implementan estas prácticas ambientales en Colombia." Estudios Gerenciales, vol. 32, num. 140, pp. 278-289, Jul - Sep 2016. doi: http://dx.doi.org/10.1016/j.estger.2016.08.004

[16] P. Zhang, J. Zhang, and M. Chen., "Economic impacts of climate change on agriculture: The importance of additional climatic variables other than temperature and precipitation," Journal of Environmental Economics and Management, vol. 83, pp. 8-31, May 2017. doi: https://doi.org/10.1016/j.jeem.2016.12.001

[17] Instituto de Hidrología, Meteorología y Estudios Ambientales (IDEAM). (2018, Oct 10). Cambio climático: Indicadores [Online]. Available: www.ideam.gov.co/web/ecosistemas/cambio-climatico

[18] OECD, CAF, ECLAC, and EC. (2019). Latin American Economic Outlook 2019: Development in transition [Online]. Available: https://www.fundacioncarolina.es/wp-content/uploads/2019/06/CEPAL-LEO-2019-EN.pdf

[19] F. Romain, La Grande Adaptation: Climat, capitalisme et catastrophe [Online]. 2016 Available: http://ise.unige.ch/isdd/spip.php?article531

[20] World Bank Group. (s.f.). DataBank. Sustainable Development Goals (SDGs) [Online]. Available: https://databank.worldbank.org/source/sustainable-development-goals-(sdgs)\# [Accessed May 2019].

[21] The Economist. (2020, Apr 23). Why tackling global warming is a challenge without precedent [Online]. Available: https://www.economist.com/schools-brief/2020/04/23/why-tackling-global-warming-is-a-challenge-without-precedent

[22] United Nations Development Programme (UNDP). (2018). Índices e indicadores de desarrollo humano: Actualización estadística de 2018 [Online]. Available: http://hdr.undp.org/sites/default/files/2018_summary_human_development_statistical_update_sp.pdf

[23] J. Sachs, G. Schmidt-Traub, C. Kroll, G. Lafortune, and G. Fuller, SDG Index and Dashboards Report 2018. Global responsibilities: Implementing the goals. New York: Bertelsmann Stiftung and Sustainable Development Solutions Network, Jul 2018.

[24] United Nations. (2020). Goal 1: End poverty in all its forms everywhere [Online]. Available: https://www.un.org/sustainabledevelopment/poverty/

[25] C. Sánchez-Páramo. (2020, Apr 23). COVID-19 will hit the poor hardest: Here's what we can do about it [Online]. Available: https://blogs.worldbank.org/voices/covid-19-will-hit-poor-hardest-heres-what-we-can-do-about-it

[26] A. Ayala, and B. Mason-Meier, "A human rights approach to the health implications of food and nutrition insecurity," Public Health, vol. 38, num. 10, pp. 1-22, 2017. doi: 10.1186/s40985-017-0056-5

[27] United Nations. (2020, Apr). A UN framework for the immediate socio-economic response to COVID. United Nations [Online]. Available: https://www.un.org/sites/un2.un.org/files/un_framework_report_on_covid-19.pdf

[28] C. Tassara, "Políticas públicas de protección social y lucha contra la pobreza en Colombia: Logros y desafíos," Papel Político, vol. 20, num. 2, pp. 323-351, Jul - Dic 2015. doi: http://dx.doi.org/10.11144/Javeriana.papo20-2.ppps

[29] OECD Data. (2019). Poverty rate [Online]. doi: 10.1787/0fe1315d-en

[30] L. F. López-Calva. (2019, Apr 10). The multidimensional poverty index: Rethinking measurement, improving governance [Online]. Available: https://mppn.org/the-multidimensional-poverty-index-rethinking-measurement-improving-governance/

[31] FAO, OPS, WFP y UNICEF, Panorama de la seguridad alimentaria y nutricional en América Latina y el Caribe 2018 [Online]. Santiago de Chile, 2018. http://iris.paho.org/xmlui/bitstream/handle/123456789/49616/9789251310595_spa.pdf?sequence=1\&isAllowed=y\&ua=1

[32] P. S. Jaramillo, "Pobreza rural en Colombia," Revista Colombiana de Sociología, num., pp. 47-62, 2006.

[33] CEPAL, Segundo Informe anual sobre el progreso y los desafíos regionales de la Agenda 2030 para el Desarrollo sostenible en América Latina y el Caribe [Online]. Santiago de Chile: Naciones Unidas, $2018 . \quad$ Available: https://repositorio.cepal.org/bitstream/handle/11362/43415/5/S1800380_es.pdf

[34] Naciones Unidas. (2018). Informe de los Objetivos de Desarrollo Sostenible [Online]. Available: https://unstats.un.org/sdgs/files/report/2018/TheSustainableDevelopmentGoalsReport2018-ES.pdf

[35] CEPAL, Ruralidad, hambre y pobreza en América Latina y el Caribe [Online]. Santiago de Chile: Naciones Unidas, 2018. Available: https://repositorio.cepal.org/bitstream/handle/11362/44371/1/S1801207_es.pdf

[36] D. Gerszon Mahler, C. Lakner, R. A. Castañeda Aguilar, and H. Wu. (2020, apr 20). The impact of COVID-19 (Coronavirus) on global poverty: Why Sub-Saharan Africa might be the region hardest hit [Online]. Available: https://blogs.worldbank.org/opendata/impactcovid-19-coronavirus-global-poverty-why-sub-saharan-africa-might-be-region-hardest

[37] T. T. Moldogaziev, J. E. Monogan, and C. Witko, "Income inequality and the growth of redistributive spending in the United States (US) states: Is there a link?,” Journal of Public Policy, vol. 38, num. 2, pp. 141-163, Jun 2018. doi: https://doi.org/10.1017/S0143814X17000125

[38] S. Hallegatte, M. Bangalore, L. Bonzanigo, M. Fay, T. Kane, U. Narloch, J. Rozenberg, D. Treguer, and A. Vogt-Schilb, Shock Waves: Managing the Impacts of Climate Change on Poverty. The World Bank, Nov 2015. doi: https://doi.org/10.1596/978-1-4648-0673-5

[39] M. del M. Hidalgo García, "La influencia del cambio climático en la seguridad alimentaria." Cuadernos de Estrategia, num. 161, pp. 6689, 2012.

[40] D. Streimikiene, "Environmental indicators for the assessment of quality of life," Intellectual Economics, vol. 9, num. 1, pp. 67-79. Apr 2015. doi: https://doi.org/10.1016/j.intele.2015.10.001 
[41] M. Velázquez. (2017, Nov 7). El Origen del índice de progreso social [Online]. Available: https://medium.com/\%C3\%ADndice-deprogreso-social-paraguay/el-origen-del-\%C3\%ADndice-de-progreso-social-fe4fd6f8ae2

[42] Social Progress Imperative (SPI). (2019). 2014-2019-SPI-Public.xlsx [Online]. Available: https://data.socialprogress.org/es/dataset/2019global-spi/resource/af1e3c94-4fb4-48aa-9548-7b2782210d26

[43] A. Aranibar, D. Maldonado, J. García, O. Jiménez y P. Caro, Índice de progreso social de las ciudades de Colombia [Online]. 2015. Available: http://manizalescomovamos.org/wp-content/uploads/2015/09/IPS-Ciudades_Resumen-Ejecutivo_VFg.pdf

[44] World Integrated Trade Solution (WITS). (2019). Import Food Products [Online]. Available: https://wits.worldbank.org/

[45] L. R. Machado-De Sousa, A. Saint Ville, L. Samayoa Figueroa, and H. Melgar Quiñonez, "Changes in food security in Latin America from 2014 to 2017," Food Security, num. 11, pp. 503-513, 2019. doi: https://doi.org/10.1007/s12571-019-00931-0

[46] Consejo Nacional de Política Económica y Social (CONPES). (2008, Mar 31). Documento Conpes DNP 113: Política Nacional de Seguridad Alimentaria y Nutricional (PSAN) [Online]. Available: https://www.valledelcauca.gov.co/descargar.php?idFile=309

[47] World Bank Group. (2020, Apr 10). Food Security [Online]. Available: https://www.worldbank.org/en/topic/food-security

[48] FAO. (2017). The food insecurity experience scale [Online]. Available: http://www.fao.org/3/a-i7835e.pdf

[49] OCDE y FAO, Perspectivas agrícolas 2016-2025. Enfoque especial: África subsahariana. París: OECD Publishing, 2016. http://dx.doi.org/10.1787/agr_outlook-2016-es

[50] N. Rodríguez-López, Programa conjunto SDG-F: Territorios productivos y con seguridad alimentaria para una población resilente y en paz, en ecosistemas estratégicos en el Cauca, Colombia [Online]. $2017 . \quad$ Available: http://www.sdgfund.org/sites/default/files/colombia_sdg_fund_final_evaluation_report.pdf

[51] Portafolio, La tasa promedio de desempleo en América Latina es del 8,8\%: OIT [Online]. 2018 Available: https://www.portafolio.co/economia/empleo/la-tasa-promedio-de-desempleo-en-america-latina-es-del-8-8-oit-521894

[52] International Labour Organization (ILO), World Employment and Social Outlook: Trends 2020. Geneve: ILO, 2020.

[53] CEPAL y OIT, Coyuntura Laboral en América Latina y el Caribe: Sostenibilidad medioambiental con empleo en América Latina y el Caribe [Online]. Santiago de Chile: Naciones $\quad$ Unidas, $2018 . \quad$ Available: https://repositorio.cepal.org/bitstream/handle/11362/44185/S1800886_es.pdf

[54] S. Freeman, "The global reality: Poverty and income inequality," Seminars in Pediatric Neurology, vol. 27, pp. 1-9, Oct 2018. doi: https://doi.org/10.1016/j.spen.2018.03.001. 